\title{
SOCIAL ACCOUNTING TO MAKE THE SOCIAL RESULTS VISIBLE
}

\author{
Ph.D. Student Gâju George Ciprian, Valahia University of Târgoviste, ciprian_giju@yahoo.com
}

\begin{abstract}
Accountability represents the direct part of the social system and its objective is to conceive this system, to measure, analyze, assess, form and control it. It is not easy to approach the social reality without correlating it to the financial, economic and administrative reality since there is a clear-cut connection between the two. The social accountability aims at balancing the social areas and the accountability practice as the former appears as a branch of the accountability within the context of scientific knowledge which offers answers to social problems, to their causes, manifestations and projections within a dynamic environment. New social responsibilities emerging in case of companies involve a growth of informational requirements both from outside and from inside for a better entity management.

This article is meant to show what social accountability is, what are its major branches and implications.
\end{abstract}

Introduction: Over the past few years the economic, political and social environment has gone through profound changes which caused a higher level of globalization and a harsher competition. The corporations have become stronger and stronger and one the issue of taking responsibility was posed they have started to attach more and more importance to the corporate social responsibility. The customers' expectations in terms of quality products and environment protection by manufacturers have increased. The same customers are now interested in both social responsibility and ethical values promoted by the companies.

The result of the consumers' pressures to encourage the large corporations to behave ethically and socially constructively was the concept of social accountability emerged in Great Britain in the 70's. Thirty years later, several small and large, private or public companies voluntarily started to show interest in establishing their social and in elaborating a series of documents to simply meet these requirements.

\section{Social accounting and SA8000}

One of the institutions researching the field of social accounting is ISEA (Institute of Social and Ethical Accountability) founded in 1996 in Great Britain with the purpose of consolidating the social accountability and the ethical behavior in the business and non-profit organizations sector. ISEA issued standards on social accounting and introduced the Accountability Standard 1000 (AA 1000) in 1999.

Nevertheless, the most relevant standard on social accounting is SA8000 developed by CEPAA (Council of Economic Priorities Accreditation Agency - USA) currently known as Social Accountability International (SAI).

The SA 8000 standard is an internationally auditable performance standard relying on International Labor Organization Conventions, on the Human Rights Declaration and the UNO Convention on child's rights. The management system of social accounting can be developed so as to integrate part of the other management systems: quality (ISO 9001:2000), environment (ISO 14001:2004), health and workforce security (OHSAS 18001:1999).

SA 8000:2001 can apply in all and any organizations which wants to: 
> Measure the companies' performance in eight key areas: child's work, forced work, occupational work and security, free association in collective associations, discrimination, disciplinary practices, working hours, remunerations;

$>$ Investigate and solve the employees' or the parties' problems, as well as take some actions with a with to correct them;

$>$ Elaborate a health and occupational security management system to eliminate or minimize the risks of employees or other parties who might be exposed to health and occupational security-related risks associated with their activities;

$>$ Implement, maintain and improve, on a permanent basis, a social accountability management system;

$>$ Make sure this system complies with the company's policy in terms of social accountability;

$>$ Prove this compliance to others;

$>$ Try to get certification/confirmation of its social accountability management system by an external organization.

Improvement of company image and efficient management of its personnel are fundamental elements to cope with the competition on the market; due to this reason, the European Union included on its agenda the distribution of Social Balance and the SA 8000 standard.

Grouping such data includes ethical, social, environmental and ecological information and can take more names: company's social information, corporate social responsibility accounting /information, social basis information, social accounting, etc.

In case of social accounting, we can identify the following principles:

- Balance between the quality and quantity ratios;

- Multi-perspective: values all opinions expressed by people or groups important to the organization;

- Comprehensive: must include all social activities of the organization;

- Credibility: records facts, keeps track of social events corroborated by the audit;

- Comparability: can constitute a basis for comparison in time and with other organizations within the same branch;

- Reporting: can be easily provided to the shareholders or other parties involved;

- Transparency: accurately shows successes and failures;

- Continuity: on a yearly basis or at certain periods.

An organization may use social accounting owing to following reasons:

$>$ To prove the benefits the man, the community and the environment have due to the company's social activities;

$>$ To accurately and honestly report on all successes of the company;

$>$ To prove the capital suppliers that the organization has had successes other than the one of surviving;

$>$ To prove the positive effects of work and efforts made by the personnel;

$>$ To offer information, other than financial ones, so as to prove that the organization is different from others;

$>$ To help an organization efficiently supervise and manage so as to improve its performance;

$>$ To acknowledge the quality standards;

$>$ To motivate a more opened and honest internal and external assessment.

\section{Main components of the social accounting}

The traditional accounting needs to change and a consequence of these new requirements. Each and every of these new information helps us identify other branches of social accounting: environmental accounting, human resources accounting, ethical accounting. 


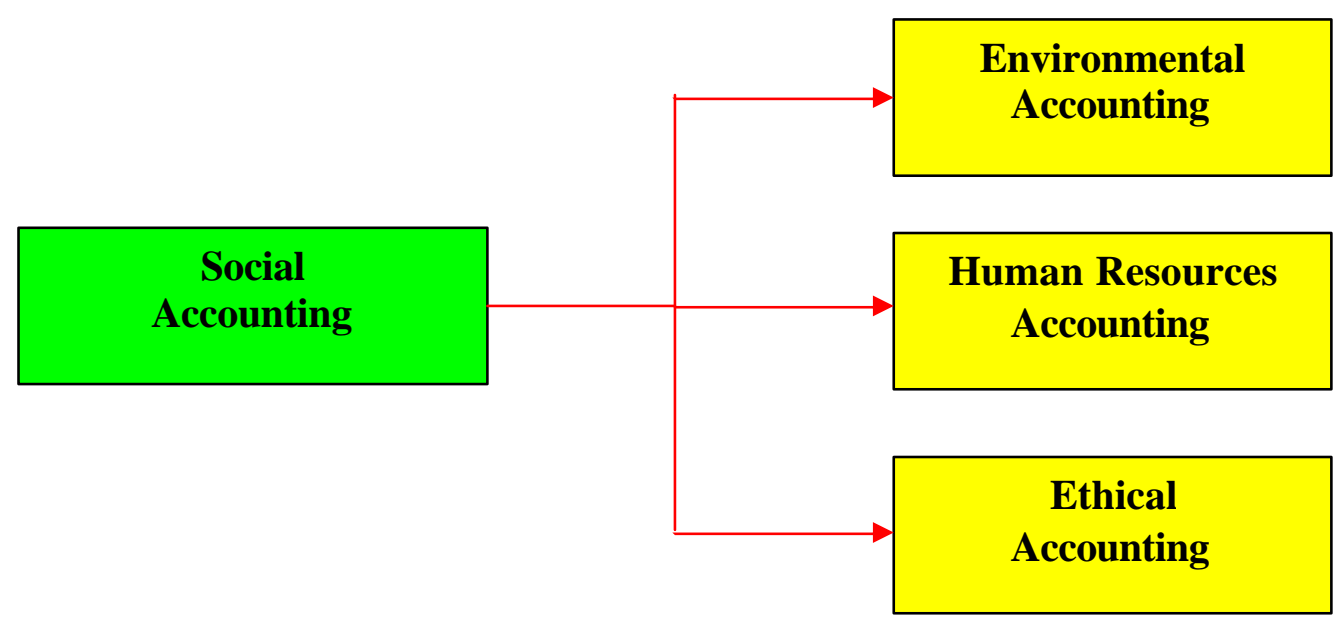

Source: own elaboration

\subsection{Environmental Accounting}

While financial accounting measures the results of the human resources consumption going up to capital resources consumption, the environmental accounting targets to quantify all natural capital resources destroyed or compromised in the production process or to assess the way good and services are utilized.

The environmental accounting has the following major objectives:

- Acknowledge and discover the negative environmental effects in the conservative accounting practice;

- Separately identify the costs and effects of the environment within the conservative accounting systems;

- Develop new forms of measurement, development and assessment;

- Develop new financial accounting and accountability systems, informational and controlling systems to allow taking advantages of the environmental benefits triggered by administrative decisions;

- Be proactive in terms of acknowledging the environmental effects existing in the conservative accounting practice.

The terminology "environmental accounting" may have several meaning depending on the accounting field it relates to, as follows:

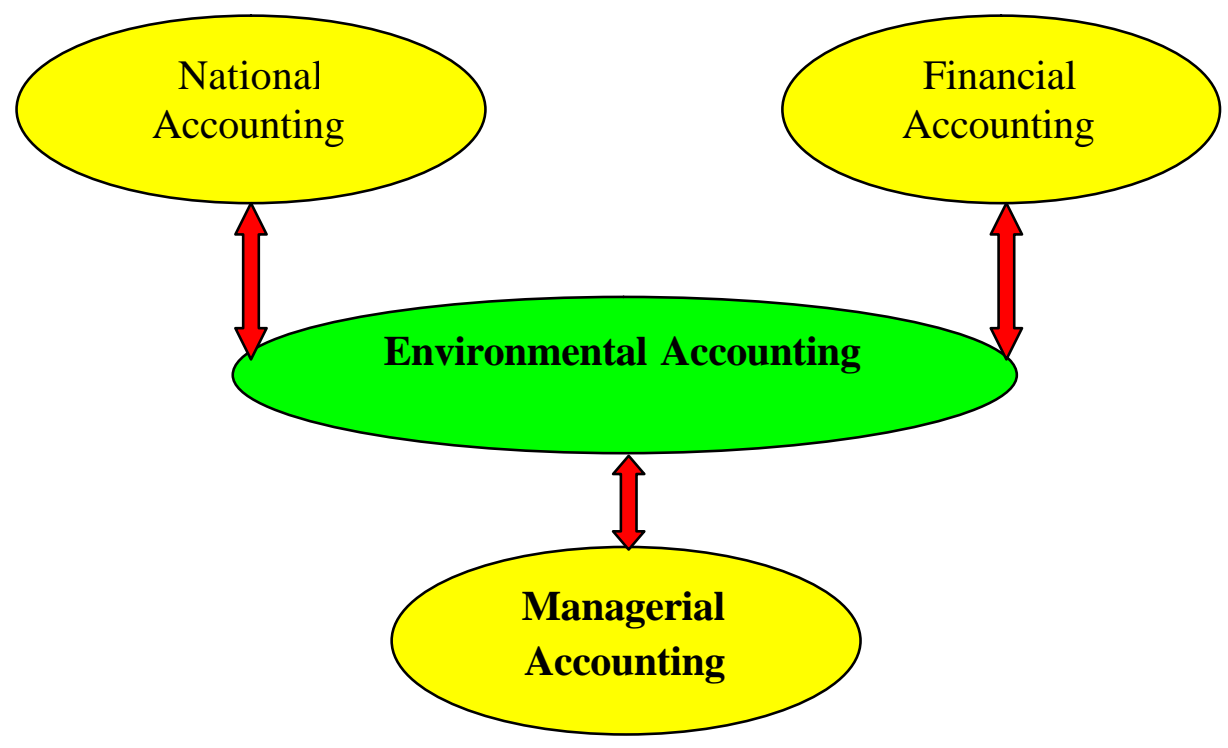

Source: own elaboration 
- Environmental accounting relating to national accounting (at a macro-economic level), which refers to natural resources, more clearly to setting out some physical or monetary ratios or to elaborating some reports on consumptions of regenerating or non-regenerating natural resources, on their quality, polluting emissions, generating residual wastes broken down by geographical areas;

The environmental accounting can also de defined as natural resources accounting and could facilitate making decisions regarding national economy, decisions which could contribute to environmental preservation.

- Environmental accounting as an aspect of the managerial accounting (at a microeconomic level), which refers to identifying, collecting and assessing information for the internal users. It consists in establishing the environmental-related costs, when assessing some capital investment projects on environment, so as to facilitate making production decisions and other decisions within the company, bearing in mind the increasingly developing interaction between the company and the environment;

- Environmental accounting relating to financial accounting (at a micro-economic level), which refers to drawing up financial reports for the external users starting from generally accepted accounting principles. Therefore, the financial accounting would play the part of assessor and publisher of the information regarding environmental responsibilities and environmental costs, from a financial standpoint, as well as other information relating to environment and climate.

2.2. Human resources accounting means incorporating in the current financial reports the information regarding assessment of one component amongst the most significant ones within the company, namely the human capital.

Similar to the environmental accounting, the human resources accounting must be included in the financial reports due to their value, at an internal level or a management level, in making decisions by the potential users, as well as at an external level, i.e. in making management decisions regarding personnel.

The emergence of the new economy, a knowledge-based one, triggered the conclusion that human resources are getting more and more important in establishing total value of an organization. The human capital refers to a series made up of knowledge and competences, abilities and professional training, inventiveness and capacity, skills and talent, learning and motivating capacity of those who are part of the organization.

2.3. Ethical accounting refers to ethical information, to the organization's ethical values, and comprises data regarding behavior in terms of consumer and community protection, monetary or service sponsorships granted to sports centers or non-profit organizations, policies and public relations, charity activities and donations, events granting equal chances, donations of equipment and know-how, etc.

The current social responsibility which organizations in Romania and worldwide faces at present claims the requisite to elaborate and present information on activities relating to the social environment. We still have no minister in charge of corporate social accounting, as there exists in Great Britain. However, this concept has started to become of major importance in large companies' minds.

Conclusions :

Accounting, as informational means, must offer information to different users of accurate information. Amongst these users, we can think of the society, in general terms, which is directly 
interested in knowing the social repercussions of the organization's activities. The social accounting information are meant not only to meet the society's requirements but also to make their contribution to creation of value inside the organization showing the extent to which the company is socially responsible and contributing to creation of intangible assets. Accounting intangible assets is not an easy process, due to both assessment difficulties and by viability in the accounting process, given the current legislation. Going beyond this issue of accounting for intangible assets, the organization must provide shareholders, customers, public administration representatives and the society, in general, with information on corporate social responsibility by its branches: the human resources, the environment and the social and ethical actions taken by the organization.

\section{Bibliography}

- Báidez, Agustín; Tejada, Angel; Rojas, Jose Antonio (1999): Los estados financieros como portadores de información medioambiental, Seminario de contabilidad - La Habana

- Darlison, Libby (2007): Social Auditing \& Accounting, National respite and social support conference, in:

http://www.interchangensw.com.au/conference2007/auditingaccounting.html

- Inchicaqui, Miguel Díaz (2003): La Contabilidad Social - Origen y Paradigmas, Colección digital de revistas in: http://sisbib.unmsm.edu.pe

- Pay, Chris (2001): Social accounting: a method for assessing the impact of enterprise development activities, EDIAIS/Traidcraft exchange

- PWC - PricewaterhouseCoopers (2005): Contabilidad Social

- SAN Social Audit NetworK: Social Accounting and Audit: a framework for social, environmental and economic (SEE) reporting in: http://socialauditnetwork.org.uk/CD2\% 20for\%20info\% 20sheet.pdf 